\title{
Apresentação
}

\section{Dossiê \\ Infâncias: educação infantil e anos iniciais do ensino fundamental}

Cassiana Magalhães ${ }^{1}$

Greice Ferreira da Silva ${ }^{2}$

A temática abordada neste dossiê permanece latente e urgente nos estudos, pesquisas e militâncias dos que veem a educação das crianças de 0 a 10 anos como fundamental para o desenvolvimento do homem e da humanidade. As questões nucleares da educação da infância emergem no cenário escolar imbricadas aos processos que medeiam a relação entre teoria e prática educativa e resvalam diretamente nas formas de ensinar e em como se aprende.

Insistentes indagações fazem-se presentes no dia a dia escolar e sustentam as discussões da obra aqui apresentada, tais como: Como garantir que as crianças tenham na escola experiências adequadas e necessárias ao seu desenvolvimento? Como organizar os conteúdos, o espaço e gerir o tempo com vistas a promover aprendizagem? Como criar necessidades humanizadoras nas crianças de modo a considerá-las também sujeitos dos processos de ensino e de aprendizagem? 0 dossiê Infâncias: Educação Infantil e Anos Iniciais do Ensino Fundamental pretendeu buscar algumas respostas a essas perguntas e alavancar as possibilidades de discussão que reverberem de maneira consoante e positiva no trabalho educativo com e para as crianças da Educação Infantil e do Ensino Fundamental.

\footnotetext{
${ }^{1}$ Docente do Departamento de Educação da Universidade Estadual de Londrina. Líder do Grupo de pesquisa Travessias Luso-Brasileiro na Educação da Infância.

${ }^{2}$ Docente do Departamento de Educação da Universidade Estadual de Londrina. Vice-líder do Grupo de Pesquisa Leitura, Biblioteca Escolar e M ediação Pedagógica.
} 
Essa edição é composta por quatro artigos. Todos eles tratam da educação destinada às crianças, embora tragam, cada qual, no cerne das reflexões, especificidades desse grande tema, com o objetivo de ampliar o debate sobre entender a/as infância/s, a criança, suas relações com o conhecimento e a formação humana.

0 primeiro deles intitula-se Educação Infantil: considerações sobre a formação de professores, o artigo problematiza a formação de professores em seu processo inicial, ressaltando as escolhas profissionais dos licenciados do Curso de Pedagogia em interface com o campo de trabalho. Valdete Côco utiliza um referencial bakhtiniano e, ainda, ancora-se em documentos oficiais, especialmente nas novas diretrizes curriculares nacionais para a formação. É importante destacar a contribuição do texto, pelo acúmulo com o tema, conforme ressaltado pela própria autora "decorrente das iniciativas de formação desenvolvidas".

0 segundo texto, 0 que cabe no currículo da educação infantil? Um convite à reflexão, das autoras, Lucinéia Maria Lazaretti e Luciana Figueiredo Lacanallo Arrais, provoca-nos a pensar sobre a organização curricular na educação infantil à luz dos documentos oficiais, ao mesmo tempo, salientando as suas fragilidades. As autoras apresentam a desarticulação existente entre objetivos e conteúdos propostos às crianças e alertam para a urgente necessidade de uma organização curricular que responda as seguintes questões: "Para quê? Para quem? Por quê? O quê? E como ensinar?". No decorrer do texto, as autoras fornecem pistas para pensar o currículo na educação infantil.

Na sequência temos 0 artigo A transição da Educação Infantil para o Ensino Fundamental: uma teoria para orientar o pensar e o agir docentes em que Suely Amaral Mello enfatiza a importância de uma formação teórica sólida para professores e professoras da Educação Infantil e do Ensino Fundamental numa perspectiva de educação que seja promotora do desenvolvimento humano. Entende que a teoria histórico-cultural oferece elementos para orientar o pensar e 0 agir docentes, o que implica a educação e os processos educativos escolares, no caso, com crianças de 0 a 10 anos. Ao abordar sobre a transição das crianças da Educação Infantil para o Ensino Fundamental ressalta que esse momento deve ser integrador e não de ruptura e/ou descontinuidade, o que requer conhecer e relevar as especificidades da idade, 
constituir um trabalho articulado entre os professores dos diferentes segmentos que possa compartilhar concepções fundamentais - de criança, infância, ensino e aprendizagem, educação, escola - para a proposição de

um conjunto de práticas sequenciais. Entende que a criança não o deixa de ser ao ingressar no Ensino Fundamental e, nas palavras da autora: "ela continua a ser criança e deve ser compreendida em sua integralidade tendo oportunidades de avançar em seu conhecimento da cultura sem abandonar a infância".

Conceição Leal da Costa e Teresa Sarmento no texto Escutar as crianças e (re) configurar identidades - interações com voz ressaltam que o processo educativo se desenvolve na base de interações entre crianças e destas com adultos; reconhecendo o lugar da criança nesse processo como um sujeito capaz, ativo, que possui vez e voz. Um sujeito social e por tal razão, a relação entre adulto e criança não pode ser uma relação de submissão, mas de interação, em que é preciso construir formas de comunicação e participação com, para e das crianças. Destacam a valorização das interações educativas em que escutar se torna um princípio fundamental na pedagogia e também na formação dos/as professores/as. Assim, entendem o processo educativo como cooperado, "o que se constitui uma exigência para a qual precisamos de uma formação e conscientização do nosso papel de adultos na promoção da autonomia e do acompanhamento de crianças em ambiente educativo". As autoras explicitam que acompanhar remonta ao desenvolvimento humano, ao processo de conhecer-se, conhecer o outro (crianças, infâncias, contextos), ter trajetórias de vida e experiências reconhecidas e valorizadas.

Sabemos que são muitas as Infâncias, mas, por meio deste dossiê, esperamos contribuir com cada uma delas. 0 trabalho pedagógico para a infância pensado por profissionais de diferentes regiões do país e até além-mar, ajudam-nos a refletir desde a relevância da formação inicial, perpassando pela intencionalidade docente, sempre respaldada em teoria, chegando na escuta das crianças em um processo educativo visto de modo cooperado.

Segue o desejo de que sejam afetados pela leitura e quiçá pela transformação da prática. As crianças merecem! 